\title{
Rancang Bangun Aplikasi Animasi Pembelajaran Matakuliah Teori Bahasa Otomata Pada Sekolah Tinggi Teknologi Pagar Alam
}

\author{
Oman Arrohman \& Cornelia Tri Wahyuni \\ Program Studi Teknik Informatika Sekolah Tinggi Teknologi Pagar Alam \\ Email : omanarrohman95@gmail.com
}

\begin{abstract}
Abstract This study aims to design and develop an application for learning animations for Teori Bahasa Otomata courses at the Pagar Alam High School of Technology that attracts students' interest. The background of this research is learning that still uses conventional media which makes it difficult for teachers so that it takes a long time and makes students bored when learning takes place. The animation application for learning the Teori Bahasa Otomata course was developed using Adobe Flash Professional CS6 and Xampp applications as server software to the MySql database. This research uses the Design Development Implementation Evaluation (ADDIE) analysis system development method. Based on the results of the expert review that has been carried out, it shows an average value of 4.90 with a very valid category. Then based on the results of the field test or alpha and beta tests obtained from the results of the pretest and posttest the average student scored 87.0 in the High category. This shows an increase in learning outcomes before and after the use of Design and Build Animation Learning Teori Bahasa Otomata.
\end{abstract}

Keywords Animation Learning, Teori Bahasa Otomata, ADDIE

\section{Pendahuluan}

Teknologi informasi atau dalam bahasa Inggris dikenal dengan istilah Information Technology adalah istilah umum untuk teknologi apa pun yang membantu dalam membuat, mengubah, menyimpan, mengkomunikasikan atau menyebarkan informasi. Teknologi informasi ini memegang peranan yang sangat penting dalam menyampaikan pesan-pesan baik dalam bentuk teks, gambar maupun suara kepada pengguna di seluruh dunia. Salah satu bidang yang berkembang pesat adalah media konvensional ke multimedia digital (Pranomo Yulianto, 2014).

Perkembangan multimedia dilihat dari masa ke masa semakin meningkat, seperti di bidang pendidikan dahulu yang masih menggunakan kapur tulis untuk menggambar, membuat teks yang tidak terlalu menarik, dan suara maupun video yang belum jelas, namun seiring berjalanya waktu dengan bantuan teknologi saat ini banyak bermunculan aplikasi pendukung multimedia yang menghasilkan tampilan menarik dalam pembelajaran sehingga membantu pengembang berinovasi untuk membuat multimedia menjadi lebih interaktif.

Multimedia interaktif dapat diartikan sebagai program aplikasi yang terdiri dari berbagai unsur media seperti teks, grafik (gambar), video, dan audio yang disajikan untuk memberi kemudahan dalam proses pembelajaran yang berguna untuk membimbing dan memperluas pemikiran para mahasiswa secara interaktif dalam bentuk animasi. (Caswito, 2013).

Dari hasil studi pendahuluan dengan metode wawancara pada dosen mata kuliah Teori Bahasa Otomata dan mahasiswa di Sekolah Tinggi Teknologi Pagar Alam didapatkan hasil bahwa pada proses pengajaran mata kuliah Teori Bahasa Otomata yang dilakukan 
saat ini masih dilakukan dengan bantuan media konvensional dan penulisan materi melalui whiteboard. Pada proses pembelajaran tersebut tentunya merepotkan pengajar sehingga memakan waktu yang lama dan membuat mahasiswa menjadi bosan pada saat pembelajaran berlangsung.

Dengan dibangunnya aplikasi animasi pembelajaran interaktif pada mata kuliah Teori Bahasa Otomata ini mampu menjadikan proses belajar mengajar yang dilakukan Sekolah Tinggi Teknologi Pagar Alam dapat berjalan sesuai dengan perkembangan dunia teknologi, dan memudahkan mahasiswa dalam melakukan belajar serta membantu meringankan pekerjaan para pengajar khusunya pengajar mata kuliah Teori Bahasa Otomata. Untuk mahasiswa nantinya akan lebih efektif karena tidak akan merasa bosan melihat maupun mendengar pemaparan materi oleh pengajar karena aplikasi ini dibuat dengan menggunakan media yang terdiri dari gabungan teks, grafik, audio, animasi dan video.

Berdasarkan latar belakang diatas peneliti merancang dan membangun aplikasi animasi pembelajaran mata kuliah Teori Bahasa Otomata pada Sekolah Tinggi Teknologi Pagar Alam dengan penjelasan materi yang lebih menarik. Dengan ini peneliti mengambil judul penelitian "Rancang Dan Bangun Aplikasi Animasi Pembelajaran Mata Kuliah Teori Bahasa Otomata Pada Sekolah Tinggi Teknologi Pagar Alam"

\section{Tinjauan Literatur}

\subsection{Sistem Informasi}

Sistem adalah sekumpulan prosedur yang berkaitan satu dengan yang lainya, dan saling terhubung dalam melakukan suatu tugas. Suatu sistem terdiri dari 3 (tiga) komponen utama, ketiga komponen tersebut adalah software, hardware dan brainware. Informasi adalah suatu data yang berupa kejadian, tempat ataupun juga perasaan yang diperoleh baik dari media cetak (koran, majalah, buku) ataupun media elektronik (Internet, televisi, radio). Sistem Informasi adalah gabungan dari 4 (empat) bagian utama, 4 (empat) bagian tersebut adalah software (perangkat lunak), hardware (perangkat Keras), infrastruktur, dan Sumber Daya Manusia (SDM) yang terlatih. Keempat bagian ini terhubung satu dengan yang lainya sehingga menciptakan suatu sistem yang mampu mengelolah suatu informasi, sehingga informasi tersebut dapat bermanfaat. (Pratama, 2016)

\section{$2.2 \mathrm{Web}$}

Web adalah aplikasi yang ada di dalam Internet yang sangat populer, senghingga banyak orang menyebutnya Internet. Didalam sebuah web terdapat informasi yang biasanya berbentuk teks, gambar, suara, dan lain-lain yang disimpan dalam sebuah Internet. Informasi tersebut biasanya ditulis dalam format HTML. Web dapat diakses menggunakan browser. Beberapa diantaranya yang cukup populer dan digunakan secara luas, seperti Microsoft Internet Explorer, Opera, Chrome dan lain-lain. (Iskandar, 2009)

\subsection{Basis Data}

Sistem basis data adalah sistem yang terkumputerisasi, bertujuan untuk memelihara data yang sudah diolah atau informasi dan membuat informasi tersebut tersedia pada saat dibutuhkan. Intinya basis data adlah media untuk penyimpanan data agar data tersebut dapat diakses dengan cepat dan mudah oleh pengguna (Rosa \& M.Shalahuddin, 2015). 


\section{Metode Penelitian}

Menurut (Mardalis, 2004) metode penelitian adalah tata cara dalam melaksanakan sebuah penelitian ilmiah, yang dipaparkan dalam sebuah proposal penelitian. Bagi seorang peneliti, metode penelitian sering kali menjadi masalah dalam sebuah penelitian. Hal itu tidak akan terjadi jika peneliti memahami prinsip dan aplikasi dari sebuah metode penelitian.

\subsection{Subyek Penelitian}

Wilayah generalisasi yang terdiri atas obyek / subyek yang mempunyai kualitas dan karakteristik tertentu yang ditetapkan oleh peneliti untuk dipelajari dan kemudian ditarik kesimpulan dinamakan populasi (Sugiyono, 2011). Menurut Riduwan dalam penelitian (Putrawansyah, 2014) populasi merupakan objek atau subjek yang berada pada suatu wilayah dan memenuhi syarat-syarat tertentu berkaitan dengan masalah penelitian.

Dari pendapat diatas maka dapat disimpulkan bahwa subjek penelitian merupakan obyek/subyek yang dijadikan wilayah generalisasi yang meliputi seluruh karakteristik/sifat yang dimiliki oleh subyek atau obyek itu. Subyek dalam penelitian ini adalah mahasiswa/i program studi teknik informatika di lingkungan Sekolah Tinggi Teknologi Pagar Alam.

\subsection{Tempat Penelitian}

Penelitian ini dilakukan di Kampus Sekolah Tinggi Teknologi Pagar Alam yang beralamat di Jl. Masik Siagim No. 75 Simpang Bacang Kelurahan Karang Dalo Kecamatan Dempo Tengah Kota Pagar Alam.

\subsection{Waktu Penelitian}

Waktu yang digunakan dalam studi pendahuluan pada penelitian ini adalah pada tanggal 15-18 November 2018 dilanjutkan dengan penulisan laporan skripsi, kemudian setelah selesai penelitian ini dilanjutkan ketahap Design and Build program serta di implementasikan dimulai dari bulan Maret - Juni 2019.

\subsection{Metode Pengumpulan Data}

Metode pengumpulan data adalah cara atau teknik yang dapat digunakan oleh peneliti untuk mengumpulkan data.

\section{Wawancara}

Wawancara adalah teknik pengumpulan data yang digunakan peneliti untuk mendapatkan keterangan-keterangan lisan melalui bercakap-cakap dan berhadapan muka dengan orang yang dapat memberikan keterangan kepada si peneliti. (Mardalis, 2004). Wawancara (Interview) dapat berupa wawancara personal (personal Interview) yang dilakukan secara pribadi, wawancara intersep (intercept Interview), wawancara telepon (telephone Interview) merupakan wawancara yang menggunakan alat komunikasi, dan wawancara terkontrol (controlled interview) wawancara yang telah dipersiapkan terlebih dahulu.

\subsection{Sistem yang sedang berjalan}

Sebelum melakukan pembuatan animasi pembelajaran, terlebih dahulu di analisa sistem pembelajaran yang sedang berlangsung dalam penyampaian materi mata kuliah Teori Bahasa Otomata pada Sekolah Tinggi Teknologi Pagar Alam. Hal ini dilakukan untuk 
mengetahui dan mempelajari kelemahan sistem pembelajaran tersebut dan masalah yang dihadapi, dimana saat ini dalam penyampaian materi tersebut masih menggunakan media konvensional, yaitu menggunakan power point dan buku sebagai alat bantu ajar dalam penyampaiannya.

\subsection{Flowchart sistem yang diusulkan}

Flowchart sistem yang diusulkan merupakan rancangan sistem yang di usulkan yang terdiri dari menu dan submenu yang di butuhkan dalam aplikasi animasi pembelajaran mata kuliah Teori Bahasa Otomata. Diawali dengan mulai kemudian intro, lalu menu utama yang berisi menu materi, evaluasi, menu petunjuk dan menu SAP.

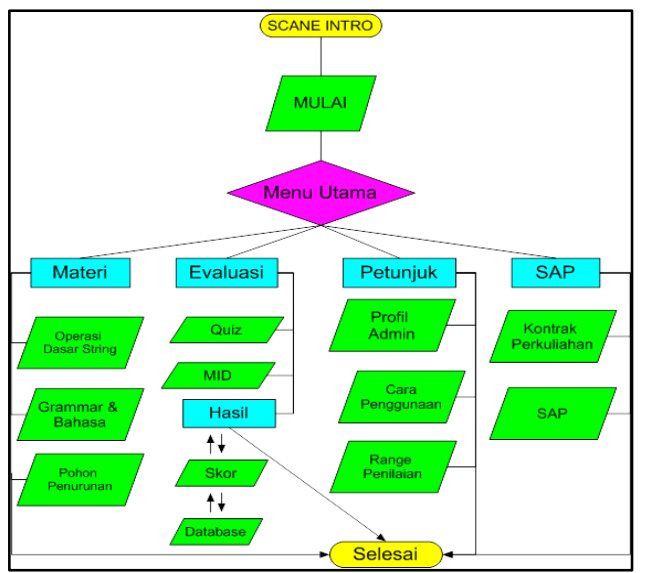

Gambar 1. Flowchart Sistem yang diusulkan

\subsection{Analisis Data Expert Review (Uji Para Ahli)}

Analisa data ini dilakukan untuk melihat tingkat kevalidan Rancang Dan Bangun Aplikasi Animasi Pembelajaran Mata Kuliah Teori Bahasa Otomata Pada Sekolah Tinggi Teknologi Pagar Alam yang di kembangkan peneliti yang telah di uji oleh Expert Review atau para ahli. Data yang telah didapat dari para ahli dijadikan acuan untuk merevisi produk sehingga menghasilkan produk yang valid. Desain produk dinilai oleh para ahli pada saat produk sudah jadi. Skor yang diperoleh dari para ahli tersebut dicari rata-ratanya dengan menggunakan rumus :

$\mathrm{R}=\frac{\sum_{i=1}^{n} V i}{n} \quad$ (Sugiyono,2011)

Keterangan:

$\mathrm{R}=$ Nilai rata-rata hasil penilaian validator

$\mathrm{Vi}=$ Skor hasil penilaian Validator ke-i

$\mathrm{N}=$ Banyaknya data

Hasil analisis tersebut di interprestasikan dengan menggunakan kategori pada tabel berikut ini

\begin{tabular}{ll}
\hline Skor & Kategori \\
\hline $4,1-5$ & Sangat Valid \\
$3,1-4$ & Valid \\
$2,1-3$ & Cukup Valid
\end{tabular}




\begin{tabular}{ll}
\hline Skor & Kategori \\
\hline $1,1-2$ & Kurang Valid \\
$0-1$ & Sangat Tidak Valid \\
\hline
\end{tabular}

\subsection{Analisis Data Test}

Analisa data tes dilakukan dengan melihat presentase ketuntasan hasil belajar mahasiswa dengan mengacu pada kriteria ketuntasan pada mata kuliah Teori Bahasa Otomata yaitu 75. Maka presentase ketuntasan (PK):

$\mathrm{PK}=\frac{\text { Jumlah Siswa yang bernilai } \geq 80}{\text { Jumlah Peserta Didik }} \times 100 \%$ (Warsita, 2008):

Setelah dianalisis kemudian dibandingkan dengan melihat tabel 7 berikut

Tabel 1. Kriteria Hasil Belajar

\begin{tabular}{lc} 
Nilai & Predikat \\
\hline $90-100$ & Sangat Baik \\
$80-89$ & Baik \\
$70-79$ & Cukup \\
$50-69$ & Kurang \\
$0-49$ & Sangat Kurang \\
\hline
\end{tabular}

Untuk menguji apakah media yang sudah di rancang oleh peneliti tersebut mempunyai efektifitas atau tidak terhadap hasil belajar maka kita hitung dengan rumus N-gain untuk melihat Efektifitas hasil belajar mahasiswa:

$\mathrm{g}=\frac{S_{\text {Post }}-S_{\text {Pre }}}{S_{\text {Maks }}-S_{\text {Pre }}}$

Keterangan:

$\mathrm{S}_{\text {post }}=$ Skor Postest

$\mathrm{S}_{\text {pre }}=$ Skor Pretest

$\mathrm{S}_{\mathrm{maks}}=$ Skor Maksimal

Kemudian hasil perhitungan $N$-gain di interpretasikan pada tabel berikut ini :

Tabel 2. Kriteria N-Gain

\begin{tabular}{ll} 
Besarnya & Interpretasi \\
\hline $\mathrm{g}>0,7$ & Tinggi \\
$0,3 \leq \mathrm{g} \geq 0,7$ & Sedang \\
$\mathrm{g}<0,3$ & Rendah \\
\hline
\end{tabular}

\section{Hasil dan Pembahasan}

Penelitian ini telah menghasilkan sebuah produk penelitian berupa Rancang Dan Bangun Aplikasi Animasi Pembelajaran Mata Kuliah Teori Bahasa Otomata Pada Sekolah Tinggi Teknologi PagarAlam. Sebelumnya pembelajaran masih menggunakan media konvensional yaitu power point dan papan tulis. Pembuatan animasi pembelajaran ini dilakukan berdasarkan model pengembangan menurut ADDIE yaitu (analysis, design, development, implementation, evaluation). 
Dalam proses testing yang terdapat pada proses pengembangan (Development) untuk mengukur kevalidan multimedia interaktif dilakukan uji alpha (uji ahli media, desain, Bahasa dan Materi) untuk mengukur keberhasilan pembelajaran uji Pre-test dan PostTest. Penjelasan hasil penelitian berdasarkan langkah-langkah pengembangan adalah sebagai berikut.

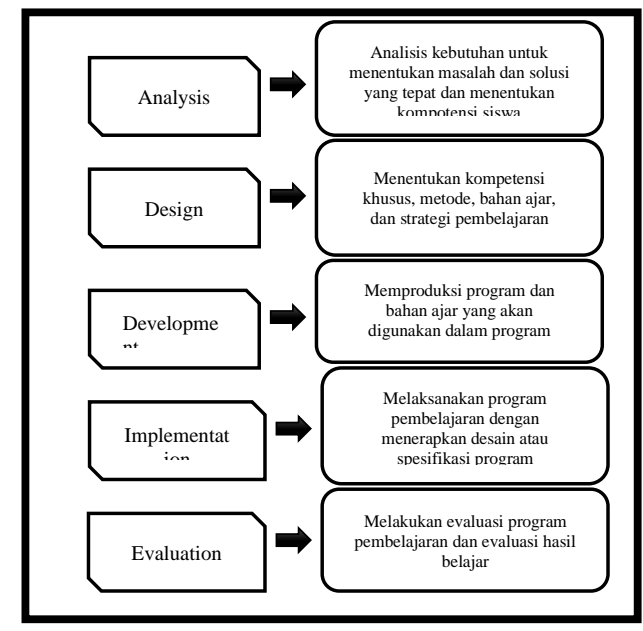

Gambar 21. Model ADDIE

\subsection{Tahap Analisis}

Tahap pertama dalam penelitian pengembangan ini adalah analisis kebutuhan dengan teknik wawancara dari mahasiswa maupun dosen mata kuliah teori bahasa otomata dan setelah produk di rancang wawancara diberikan kepada Exspert Review untuk menguji validitas produk yang telah dirancang.

\subsection{Tahap Perancangan (Desain)}

Tahap perencanaan merupakan tindak lanjut dari analisis kebutuhan, perencanaan animasi pembelajaran Teori Bahasa Otomata disesuaikan dengan analisis kebutuhan. Pada tahap ini ada berbagai macam kegiatan yang harus dilakukan antara lain sebagai berikut:

\subsection{Tahap Development}

(Pengembangan)

Dalam tahap Development pengembangan, kerangka yang masih konseptual tersebut direalisasikan menjadi produk yang siap di implementasikan yaitu dengan melalui tahap penilaian ahli validitas yaitu Penilaian Ahli Bahasa, Ahli Materi dan Ahli Desain.

\section{Ahli Bahasa}

Validasi yang dilakukan oleh ahli Bahasa digunakan untuk menilai produk Animasi Pembelajaran Teori Bahasa Otomata. Untuk menilai kesesuaian bahasa yang di sempurnakan, penilaian ini bermaksud melihat layak atau tidak media tersebut untuk di impelmentasikan kepada mahasiswa.

\section{Ahli Materi}

Setelah aplikasi animasi pembelajaran interaktif selesai dibuat dilakukan validasi ahli materi. Validasi ahli materi digunakan untuk menilai materi yang telah disusun dalam animasi pembelajaran mata kuliah Teori Bahasa Otomata Sekolah Tinggi Teknologi Pagar Alam. 


\section{Ahli Desain}

Validasi yang dilakukan oleh ahli Desain digunakan untuk menilai produk media pembelajaran berbasis multimedia interaktif. untuk menilai gambar, animasi, daya dukung musik, pemilihan warna, dan tampilan layar. Penilaian ini bermaksud melihat layak atau tidak media tersebut untuk di impelmentasikan kepada mahasiswa.

\section{Ahli Media}

Validasi yang dilakukan oleh ahli Media digunakan untuk menilai produk media animasi pembelajaran berbasis multimedia interaktif. untuk menilai kesesuaian media yang akan digunakan pada subjek penelitian dan keakuratan pada saat aplikasi digunakan.

Hasil rekapitulasi dihasilkan setelah mendapatkan saran dari validator. Maka berdasarkan hasil kuisioner tersebut didapatkan hasil pada uji bahasa didapatkan skor rata-rata 5 dengan kriteria sangat baik atau sangat valid, kemudian uji materi didapatkan skor 5 dengan kriteria sangat valid uji desain mendapatkan skor 4,80 dengan kriteria sangat valid dan ahli media mendapatkan skor 4,80 dengan kriteria sangat valid, sehingga hasil ratarata 4,90 dengan kategori sangat valid. Hal ini menunjukan animasi pembelajaran Teori Bahasa Otomata sudah menunjukan produk yang sangat valid.

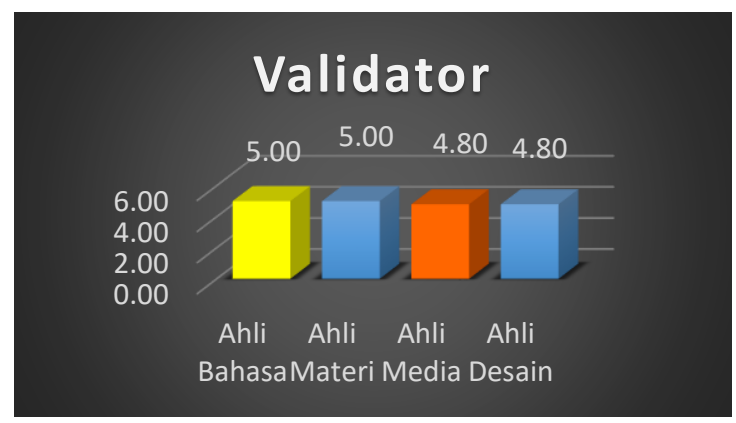

Gambar 22. Nilai Validator

\subsubsection{Implementasi (Field test)}

Setelah diperoleh produk yang valid yang telah di uji validasi dan maka selanjutnya di implementasikan atau di uji langsung ke mahasiswa dengan cara field test, Field test ini dilakukan kepada mahasiswa Sekolah Tinggi Teknologi Pagar Alam. Sebelum memulai pembelajaran penulis melakukan pre-test untuk mengukur kemampuan awal mahasiswa terlebih dahulu kemudian setelah proses pembelajaran selesai berlangsung dilakukan post-test untuk mengetahui perbandingan nilai pre-test dan post-test setelah dilakukan pembelajaran menggunakan Animasi Pembelajaran mata kuliah Teori Bahasa Otomata pada Sekolah Tinggi Teknologi Pagar Alam. 
Dari hasil field test didapatkan nilai rata-rata yang dicapai mahasiswa saat pre-test adalah 37,5 dengan kategori sangat kurang, sedangkan untuk hasil post test didapatkan hasil 87,0 dengan kategori baik. Maka dapat kita lihat dari hasil tersebut bahwa terjadi peningkatan hasil belajar mahasiswa, hal ini terlihat dari peningkatan hasil rata-rata skor pre-test dan post-test. Dengan ini dinyatakan bahwa mahasiswa sudah mencapai kriteria ketuntasan minimal yaitu 75. Kemudian berdasarkan data tesebut didapatkan N-gain sebesar 0,8 yang menunjukan bahwa animasi pembelajaran Teori Bahasa Otomata memiliki kefektifan terhadap hasil belajar mahasiswa.

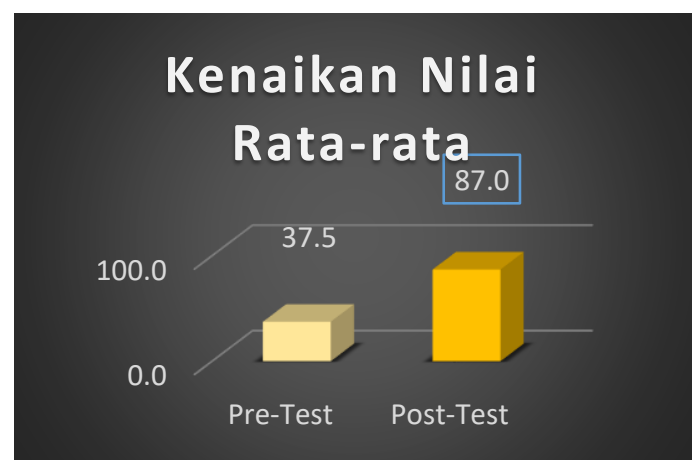

Gambar 23. Selisih Nilai Rata-Rata Pre test dan Post test

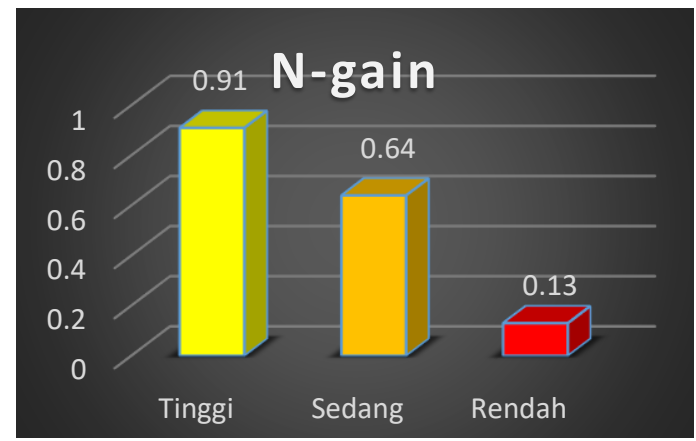

Gambar 24. Rekapitulasi N-gain Mahasiswa

Berdasarkan data rekapitulasi $\mathrm{N}$-gain diatas didapatkan bahwa rata-rata skor $N$-gain pada mahasiswa dengan kecerdasan tinggi 0,91 dengan kecerdasan sedang didapatkan rata-rata skor 0,64 dan mahasiswa dengan kecerdasan rendah rata-rata skor 0,13. Pada rekapitulasi ini mendapatkan nilai rata-rata skor 0.8 dengan kriteria Tinggi.

\section{Kesimpulan}

1. Dalam penelitian ini telah menghasilkan Animasi pembelajaran Teori Bahasa Otomata pada program studi Teknik Informatika Sekolah Tinggi Teknologi Pagar Alam.

2. Animasi pembelajaran Teori Bahasa Otomata menggunakan aplikasi Adobe Flash Professional CS6 dan Database MySql.

3. Animasi pembelajaran Teori Bahasa Otomata di Sekolah Tinggi Teknologi Pagar Alam dinyatakan valid. Data diperoleh dari komentar dan saran pada lembar validasi yang diberikan oleh ahli bahasa ahli materi ahli media dan ahli desain. Animasi pembelajaran Teori Bahasa Otomata ini memiliki kriteria valid ditinjau dari aspek isi/ materi, aspek penggunaan bahasa, aspek kelengkapan format bahan ajar, dan aspek rencana pembelajaran, Hasil validasi ahli Bahasa menunjukkan bahwa animasi pembelajaran interaktif ini mempunyai kriteria sangat baik dengan rata-rata skor 4 
sedangkan hasil validasi ahli materi menunjukkan bahwa multimedia pembelajaran interaktif ini sangat baik dengan rata-rata skor 5 dan hasil validasi ahli desain menunjukkan bahwa animasi pembelajaran interaktif ini sangat baik dengan rata-rata skor 4,8 dengan kriteria sangat valid dengan hasil rata-rata 4,8 dengan kategori sangat valid.

4. Hasil field test atau uji alpa dan beta data diperoleh dari hasil pre test dan post test pada uji lapangan. Hasil rata-rata pretest mahasiswa termasuk pada kategori "kurang cukup" dengan nilai rata rata 43 , hasil rata-rata pos-test mahasiswa termasuk pada kategori "baik" sehingga mendapatkan $N$-Gain dengan kategori "tinggi", yaitu dengan nilai rata rata $85 \mathrm{Hal}$ ini menunjukkan terjadi peningkatan hasil belajar sebelum dan sesudah penggunaan Animasi pembelajaran Teori Bahasa Otomata di Sekolah Tinggi Teknologi Pagar Alam.

\section{Referensi}

Caswito. (2013). Implementasi Media Pembelajaran Transformasi Wavelet Pada Matakuliah Pengolahan Citra Berbasis Multimedia. Jurnal Sarjana Teknik Informatika, 656-665.

Mardalis, D. (2004). metode penelitian suatu pendekatan proposal. Jakarta: PT Bumi Aksara.

Pranomo Yulianto, F. N. (2014). Rancang Bangun Aplikasi Simulasi Penggunaan Kamera DSLR. Jurnal Sarjana Teknik Informatika, 1-10.

Putrawansyah. (2014). Pengembangan Multimedia Interaktif Model Permainan Berbasis Android Pada Mata Pelajarn Tata Surya di Sekolah Menegah Atas. Jurnal Informatika.

Sugiyono, P. D. (2011). Metode Penelitian Kombinasi (Mixed Methods). Bandung: Alfabeta.

\section{Copyrights}

Copyright for this article is retained by the author(s), with first publication rights granted to the journal.

This is an open-access article distributed under the terms and conditions of the Creative Commons Attribution license (http://creativecommons.org/licenses/by/4.0/) 